\title{
Population estimators and adult sex ratio for a population of Bolitoglossa altamazonica (Caudata: Plethodontidae)
}

\author{
Doris Laurinette Gutiérrez-Lamus ${ }^{1, *}$,John Douglas Lynch', Germán C. Martínez-Villate² \\ ${ }^{1}$ Instituto de Ciencias Naturales, Amphibian's Laboratory, Universidad Nacional de Colombia, Bogotá, Colombia. \\ ${ }^{2}$ Faculty of Veterinary Medicine and Husbandry, Fundación Universitaria San Martín, Sede Bogotá, Colombia. \\ * Correspondence: Cra. 4 \# 24-59 apt. 1504, Bogotá, Colombia. Phone: 57-1-4794101, E-mail: dlgutierrezl@unal.edu.co
}

Received: 17 March 2011; received in revised form: 10 October 2011; accepted: 3 November 2011.

Bolitoglossa altamazonica is the species of plethodontid salamander with the widest distribution in the tropics. However, while aspects related to population size, survival rates, recruitment, sex ratios along with other life history traits are well documented for temperate salamanders, such information is relatively scarce for tropical species. We conducted an intensive capture-recapture study on a population of B. altamazonica. We used the Jolly-Seber method to estimate three parameters (size, recruitment and survivorship) for the population as a whole, as well as for males, females and juveniles separately. All these parameters varied monthly for each class and the entire population. Juvenile recruitment occurred between november and july. Survivorship of juveniles increased when there was no recruitment at all. The adult sex ratio during the breeding season was significantly biased towards females (up to 1:3 depending on the month).

Key words: population size; recruitment; salamanders; sex ratio; survivorship.

Estimadores de población y razón de sexos en una población de Bolitoglossa altamazonica (Caudata: Plethodontidae). Bolitoglossa altamazonica es la especie de pletodóntido con distribución más amplia en los trópicos. Sin embargo, mientras que los aspectos relacionados con el tamaño de la población, tasa de supervivencia, reclutamiento, razón de sexos y otras características de la historia vital están bien documentados en salamandras de zonas templadas, la información para especies tropicales es relativamente escasa. Llevamos a cabo un estudio intensivo de marcaje-recaptura en una población de $B$. altamazonica. Utilizamos el método de Jolly-Seber para estimar tres parámetros (tamaño, reclutamiento y supervivencia) tanto para el conjunto de la población como para machos, hembras y juveniles por separado. Todos los parámetros estimados experimentaron variaciones mensuales en cada una de las clases así como en el conjunto de la población. El reclutamiento de los juveniles sucedió entre noviembre y julio. La supervivencia de los juveniles se incrementó cuando no existía reclutamiento. La razón de sexos de la población adulta durante el periodo reproductor estuvo significativamente sesgada en favor de las hembras (hasta 1:3 dependiendo del mes).

Key words: razón de sexos; reclutamiento; salamandras; supervivencia; tamaño de población.

Reports on declining and disappearing amphibian populations have received a great deal of attention in recent years (PECHMANN \& WILBUR, 1994). These population fluctuations are believed to be the result of natural events (PeChmann \& Wilbur, 1994) or environmental perturbations (POUNDS et al., 1997), and differentiating problematic declines from natural fluctuations in populations is an issue of particular difficulty in applied ecology (Pechmann et al., 1991). One-third of all amphibian species worldwide is endangered or threatened with extinction (STUART et al., 2004). Efforts to understand the causes of this 
alarming decline, known as the global amphibian crisis, have focused primarily on frogs; comparatively little attention has been paid to salamanders (LIPS, 1998; PARRA-OlEA et al., 1999; Whitfield et al., 2007). A reason for this bias includes the fact that most salamanders are secretive in nature, so populations trends may not be as apparent as in frogs, but the global amphibian crisis, usually discussed in terms of frogs, clearly involves neotropical salamanders as well (Rovito et al., 2009).

Declining trends are impossible to detect without long-term abundance-based data on population densities collected by using a consistent methodology. Although those data sets are exceptionally rare, they are critical to understand the full extent of the global amphibian crisis (WhitField et al., 2007). An assessment of the status and conservation of amphibians requires an expanded, regional perspective (HeCnar \& M'Closkey, 1996); however, few estimates of amphibian natural history parameters exist against which to judge the extent of additional mortality (BLACKWEll et al., 2004).

Population size indicates how the reproductive health for a given population is, and survivorship often explains a large portion of an individual's lifetime reproductive success (Olgun et al., 2001). Therefore, analyses of the variation of life history parameters such as survival rates and recruitment over time are of major importance not only for understanding the life history of a species (FLATT et al., 1997), but also for providing an expanded regional perspective for conservation and management (BLACKWELL et al., 2004).

In ecological studies, the adult sex ratio, defined as the proportion of reproductive females and males within the breeding popu- lation, is considered a key parameter in understanding sexual selection, mating behaviour, and population dynamics (KVARNEMO $\&$ AHNESJÖ, 2002). According to classical sex allocation theories, in natural populations a balanced sex ratio should be maintained in the long term by a selective advantage to the parents producing the rarest sex (RANTA et al., 2000). However, in amphibians, the relative numbers of sexually active males and females show large interspecific variations depending on the mode of reproduction, mating system and resource distribution (ZUG et al., 2001).

All neotropical salamanders belong to the tribe Bolitoglossini (family Plethodontidae); these salamanders have direct development of young inside terrestrially laid eggs (WAKE, 1966). The supergenus Bolitoglossa contains about two-thirds of plethodontid species and about $40 \%$ of all species of salamanders (AмphiBiaWeB, 2011). Bolitoglossa altamazonica occurs on the eastern slopes of the Andes from Venezuela and Colombia, through Ecuador, Peru and Bolivia, and as far east as eastern Brazil. Because of its wide distribution and presumed large populations, $B$. altamazonica is listed as Least Concern in the IUCN Red List (AzEVEDO-RAMOs et al., 2009).

The main goals of this study were to examine three population parameters (size, survivorship and recruitment) for a population of $B$. altamazonica and to evaluate whether the adult sex ratio is balanced and constant through time. The present study contributes to the knowledge of amphibian life history by documenting temporal population parameters of a population of $B$. altamazonica. This dataset provides the best opportunity to examine changes in salamander populations over 
time, thus serving as a reference for comparison to populations in other localities from Colombia and along its distribution range.

\section{MATERIALS AND METHODS}

The study site, Jardín Botánico de Villavicencio, is a local natural reserve since 1983 located in Villavicencio City, Meta, Colombia (040 09' 09" N, 730 39' 15" W) at $640 \mathrm{~m}$ above sea level. It is a humid tropical forest (HoLDRIDGE et al., 1971) with mean annual rainfall, temperature and relative humidity of $4531 \mathrm{~mm}, 25.9^{\circ} \mathrm{C}$ and $76 \%$, respectively. The rainfall regime is unimodal with a maximum peak of rains from May to June. The dry season usually extends from December to March (data recorded from the nearest weather station: Vanguardia Instituto de Hidrología, Meteorología y Estudios Ambientales de Colombia).

At the study site, we established a $7300 \mathrm{~m}^{2}$ plot. We captured salamanders within this plot by visual encounter (CRUMP \& SCOTT, 1994; ANGUlo et al., 2006). Two experienced researchers looked for salamanders during eight nights (19:00-02:00), monthly from April 2008 to November 2008 with an additional sampling performed in January 2009. All surveys were conducted at night because the focal species is nocturnal and surface activity occurs at night. We marked animals using freeze branding with liquid nitrogen (DAUGHERTY, 1976). Individual identification was achieved by combinations of marks in fifteen body locations (modified from NisHIKAWA \& SERVICE, 1988), five on each side of the body and five mid-dorsally according to the following distribution: anterior and posterior to the fore limb, midbody, anterior and posterior to the hind limb.
We measured snout-vent length (SVL: tip of the snout to posterior margin of the vent) using a vernier calliper after restraining the salamanders in a plastic bag. Adults were sexed in accordance with their size (SVL) and secondary characters; during the breeding period, mature males had an enlarged, disc-like mental gland in the anterior region of the lower jaw (SVL: 34.58-44.86 mm) whereas mature females were gravid (SVL: 36.34-57.84 mm). We used these SVLs as a reference for sexing individuals out of the breeding season; however, because of the big overlap in size between sexes, only large females (SVL > $44.86 \mathrm{~mm}$ ) and small males $(\mathrm{SVL}<36.34 \mathrm{~mm})$ could be sexed in the field. All specimens with an SVL below $34.00 \mathrm{~mm}$ without sexual secondary characters were classified as juveniles. We returned all animals to the spot where we captured them after data collection and marking.

The primary goal of the mark-recapture analysis was to estimate population size, survival and recruitment. In an open population that is affected by mortality and migration, variable survival rates are more biologically realistic than fixed ones (DONNELLY \& GUYER, 1994; KREBS, 1999). Survival can be estimated using standard mark-recapture methodology (LEBRETON et al., 1992). Local survivorship represents the probability of surviving from month (i) to month $(i+1)$, and is affected by both mortality and permanent emigration. Local recruitment is the number of new animals in the population at time i per animal in the population at time i - 1 (Pradel, 1996), and it includes in situ reproduction and immigration. We included sex and age as grouping factors in the model selection procedure to allow for testing sex- and age-specific effects on the parameters of interest. We analyzed 
mark-recapture data using Cormack JollySeber (CJS) and Pradel survival and recruitment extensions of Program MARK version 5.0 (White \& Burnham, 1999). We used an overall model selection procedure before parameter estimation. Ten a priori candidate models offered different biological representations of the role of capture probability among sexes and ages (adult or juvenile). Rather than including all possible permutations in the primary model selection procedure, we initially tested four models to evaluate sex differences in detectability and survival; then, we tested four additional models accounting for possible age differences in these variables. Parameters in the candidate models were either allowed to vary over time or to remain constant. Model selection was based on the small-sample Akaike's information criterion (AICc; Burnham \& ANDERSON, 2002). Some parameters were estimated after 15000 simulations using Markov chain Monte Carlo (MCMC), keeping all the other parameters that did not have standard errors extremely high or low fixed. We used the Jolly-Seber original model (Jolly, 1965; SEBER, 1965) to estimate population size, since program Mark never reached numerical convergence. Adult sex ratio was expressed as the relative proportions of estimated mature males and females, and deviations from a 1:1 ratio were tested through a Chi-square test.

\section{RESULTS}

We captured 880 individuals of $B$. altamazonica, 244 of which were recaptured for a total of 1124 captures in nine months. Monthly captures regardless of sex or age ranged from 64 to 184 individuals, and fluctuated following the same pattern as rainfall, with a peak of captured salamanders in June (Fig. 1). Because of the intense sampling, frequency of captures of new individuals declined rapidly over time, in spite of which we captured new individuals in all months.

Table 1: Model rankings to evaluate sex and age effects on survival (Phi) and detectability (p), using the Cormack-Jolly-Seber (CJS) extension, and age and time effects on survival and recruitment (f), using the Pradel extension, in a population of Bolitoglossa altamazonica. Models are listed in decreasing order of support using Akaike’s Information Criterion. $\mathrm{g}$ = gender/age-dependent, $\mathrm{t}$ = time-dependent.

\begin{tabular}{|c|c|c|c|c|c|c|}
\hline Extension & Model & $\mathrm{AICc}$ & $\begin{array}{l}\text { Delta } \\
\text { AICc }\end{array}$ & $\begin{array}{l}\text { AICc } \\
\text { weight }\end{array}$ & $\begin{array}{l}\text { Model likeli- } \\
\text { hood }\end{array}$ & Deviance \\
\hline \multirow[t]{4}{*}{ CJS (Sex) } & $\operatorname{Phi}(\mathrm{t}) \mathrm{p}(\mathrm{t})$ & 203.87 & 0.00 & 0.669 & 1.00 & 20.85 \\
\hline & $\operatorname{Phi}\left(g^{*} t\right) p\left(g^{*} t\right)$ & 206.41 & 2.53 & 0.188 & 0.28 & 12.81 \\
\hline & $\operatorname{Phi}\left(g^{*} t\right) p(t)$ & 207.84 & 3.97 & 0.092 & 0.137 & 18.52 \\
\hline & $\operatorname{Phi}(\mathrm{t}) \mathrm{p}\left(\mathrm{g}^{*} \mathrm{t}\right)$ & 209.09 & 5.21 & 0.049 & 0.074 & 19.76 \\
\hline \multirow{4}{*}{ CJS (Age) } & $\operatorname{Phi}(t) p\left(g^{*} t\right)$ & 1763.93 & 0.00 & 0.882 & 1.00 & 239.94 \\
\hline & Phi $\left(g^{*} t\right) p\left(g^{*} t\right)$ & 1768.23 & 4.299 & 0.103 & 0.116 & 229.49 \\
\hline & $\operatorname{Phi}(\mathrm{t}) \mathrm{p}(\mathrm{t})$ & 1772.19 & 8.263 & 0.014 & 0.016 & 264.82 \\
\hline & $\operatorname{Phi}\left(g^{*} t\right) p(t)$ & 1777.36 & 13.426 & 0.001 & 0.001 & 253.37 \\
\hline \multirow[t]{2}{*}{ Pradel } & Phi (t) $p\left(g^{*} t\right) f\left(g^{*} t\right)$ & 5444.219 & 0.00 & 0.984 & 1.00 & 242.66 \\
\hline & Phi (t) $p\left(g^{*} t\right) f(t)$ & 5452.48 & 8.26 & 0.016 & 0.016 & 257.28 \\
\hline
\end{tabular}




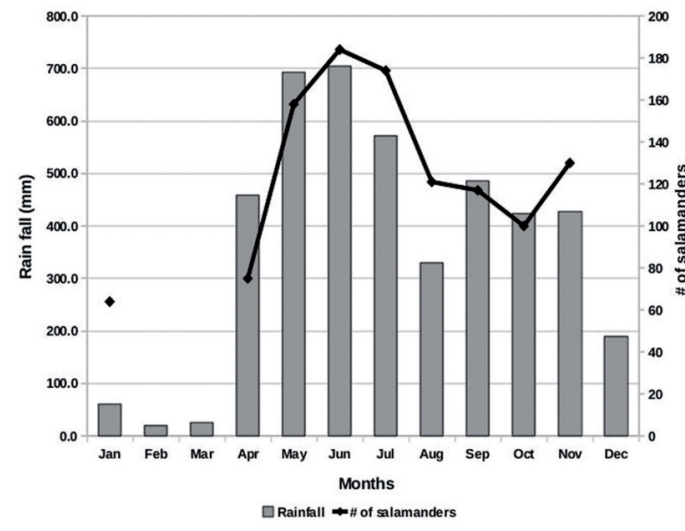

Figure 1: Monthly variation in the number of captured salamanders (black line) and its relationship with rainfall values (grey bars).

From the set of models used to evaluate sex effects on survival and detectability, the model that fitted better into our capturerecapture history was that considering both parameters to vary over time without effects of sex (Table 1). Thus, we did not include in subsequent analyses the effects of sex on these two variables. The second set of models, used to evaluate age effects on survival and detectability, supported the time-varying detectability, revealing differences between ages in detectability but not in survival (Table 1). Finally, the comparison of the two models to evaluate age and time effects on recruitment showed that this parameter varied as a function of both factors (Table 1).

Population size estimates fluctuated between months, ranging from 582 in May to a maximum of 2165 individuals in October. Survivorship also fluctuated between months, with the highest trustable estimate in July. Although the estimated survivorship for September was higher than that of July, we disregarded it because of its large standard error; such a high value for survivorship is a mathematical artefact produced by the large number of individuals marked in October in contrast with the low number of individual marked during September (Table 2).

Using the maximum number of salamanders estimated by the Jolly-Seber method, the population density within the studied plot would be 0.23 salamanders $/ \mathrm{m}^{2}$. For density estimation, we used the population size obtained in October (highest value) because a good number of specimens were already marked by that month (752), and salamanders were highly active because of favourable weather conditions, allowing us to calculate population density without underestimations.

For estimating juvenile population parameters, we used 412 marked specimens and 69 recaptures, for a total of 480 captures. We identified an individual as juvenile in May $(\mathrm{SVL}=34.6 \mathrm{~mm})$, but when we recaptured it 30 days later it showed a visible and completely developed mental gland $(\mathrm{SVL}=38.24 \mathrm{~mm})$. Between-months recruitment was highly variable (Table 3). The highest juvenile recruitment occurred in June and July, while

Table 2: Population size (N) and survival (Phi) estimates $( \pm$ SE) for a population of Bolitoglossa altamazonica. No data from January were calculated because, due to the absence of sampling in December, they did not meet the Jolly-Seber method requirement of consecutive samplings.

\begin{tabular}{ccc}
\hline \hline Month & N & Phi \\
\hline April & - & $0.342( \pm 0.107)$ \\
May & $582( \pm 253)$ & $0.847( \pm 0.140)$ \\
June & $1348( \pm 350)$ & $0.779( \pm 0.125)$ \\
July & $1344( \pm 280)$ & $0.880( \pm 0.162)$ \\
August & $1267( \pm 275)$ & $0.830( \pm 0.171)$ \\
September & $776( \pm 150)$ & $1.950( \pm 0.196)$ \\
October & $2165( \pm 896)$ & $0.825( \pm 0.362)$ \\
November & $1298( \pm 560)$ & $0.281( \pm 17.995)$ \\
January & - & - \\
\hline
\end{tabular}


Table 3: Juvenile and adult recruitment (f) and detectability $(\mathrm{p})( \pm \mathrm{SE})$ in a population of Bolitoglossa altamazonica.

\begin{tabular}{ccccc}
\hline \hline Month & f & Adults & Juveniles \\
& & p & f & p \\
\hline May & $1.145( \pm 0.276)$ & $0.174( \pm 0.102)$ & $7.558( \pm 1.709)$ & $0.242( \pm 0.000)$ \\
June & $0.825( \pm 0.219)$ & $0.152( \pm 0.050)$ & $0.061( \pm 0.124)$ & $0.238( \pm 0.174)$ \\
July & $0.122( \pm 0.274)$ & $0.136( \pm 0.037)$ & $0.320( \pm 0.127)$ & $0.105( \pm 0.037)$ \\
August & $-0.008( \pm 0.004)$ & $0.127( \pm 0.033)$ & $0.011( \pm 0.223)$ & $0.111( \pm 0.0321)$ \\
September & $0.268( \pm 0.123)$ & $0.200( \pm 0.045)$ & $0.006( \pm 0.062)$ & $0.077( \pm 0.017)$ \\
October & $0.407( \pm 0.182)$ & $0.120( \pm 0.027)$ & $0.006( \pm 0.089)$ & $0.071( \pm 0.016)$ \\
November & $0.327( \pm 0.227)$ & $0.082( \pm 0.039)$ & $0.024( \pm 0.093)$ & $0.064( \pm 0.015)$ \\
January & $0.027( \pm 1.085)$ & $0.104( \pm 0.021)$ & $0.011( \pm 0.130)$ & $0.124( \pm 0.055)$ \\
\hline
\end{tabular}

no new juveniles entered the population between September and October. We did not take into account juvenile recruitment estimates in May because of the high standard error. We performed estimates for adults from 468 individuals, 175 of which were recaptured for a total of 643 captures. Adult recruitment was highest in June and dropped along with the rainfall; in August-September no new adults entered the population (Table 3).

Using the 100 males and 245 females captured during the breeding season, which runs from January to July (GUTIÉRREZ-LAMUS, 2009), we found a significantly female-biased sex ratio that ranged between months from $1: 2$ to $1: 3$ (Table 4 ).

\section{DisCUSSION}

The results from this study are the first of its kind for B. altamazonica and contribute to the knowledge about this population in regards to its size, survivorship, recruitment and adult sex ratio.

The key estimates for many ecologists using the CJS model on capture-recapture data are the survival rates, with the capture probabilities often viewed as little important nuisance para- meters (PledGER et al., 2003). Numerous authors have suggested that this assumption is met as capture probability is likely to vary among demographic groups over time (WILlsON et al., 2011). The mistake of assuming constant capture probability when variation actually exists can bias estimates of abundance or recruitment (POLLOCK et al., 1990; BAILEY et al., 2004). Imperfect detectability also extends to the estimation of survival (MAZEROLle et al., 2007). Adjusted population estimates, which estimate the "true" population based on capture-recapture techniques, are labour-intensive but may yield a more accurate picture of the number of salamanders present in a population (JUNG et al., 2000).

Table 4: Chi-square test to analyse the sex ratio obtained in a population of Bolitoglossa altamazonica. The null hypothesis is a one-to-one sex ratio. $P$-values in bold face are significant.

Month N (males) N (females) Sex ratio $\chi^{2}($ d.f. $=1) \quad P$

\begin{tabular}{cccccc}
\hline April & 17 & 31 & $1: 1.8$ & 4.0833 & 0.0433 \\
May & 17 & 46 & $1: 2.7$ & 13.3492 & 0.0000 \\
June & 29 & 67 & $1: 2.3$ & 15.0417 & 0.0003 \\
July & 23 & 64 & $1: 2.8$ & 19.3218 & 0.0000 \\
January & 14 & 37 & $1: 2.6$ & 10.3726 & 0.0013 \\
Total & 100 & 245 & $1: 2.45$ & 60.9420 & 0.0000 \\
\hline
\end{tabular}


According to recruitment estimates, most juveniles enter the population in July, and recruitment gradually decreases during subsequent months along with rainfall. Juvenile recruitment was almost null between August and October, but in November new young individuals entered the population again. Nevertheless, such results can be sample size artefacts because we marked young individuals during those months when recruitment estimated by Pradel method was close to zero. The method does not provide estimates for the first month of sampling. For this reason, we believe that juvenile recruitment occurs continually from November through July. The intensity of recruitment depends on the effective size of the breeding population and the survivorship of the eggs (DuEllman \& Trueb, 1994), as well as the volume of captures. According to the estimates for both adults and juveniles, most recruitment occurs between June and July, when rainfall reaches maximum levels. On the other hand, new adults do not enter the population when rainfall decreases (August-September).

Several reasons could have caused the fluctuations in our estimates; first, our inability to find and mark brooding females; second, sampling during rainy nights when activity notably decreased; third, the behavioural thermoregulation demonstrated in plethodontids (SPOTILA, 1972; FEDER, 1982), consisting in that animals select optimal temperatures by moving to preferred parts of the gradient. If optimal temperatures were achieved in the litter, we could hardly find animals there. Fourth, the cutaneous gas exchange may account for more than $90 \%$ of the exchange in plethodontids, which might force animals to use microhabitats with adequate humidity and temperature in order to minimize the risk of water loss (SPOTILA 1972). Salamander capture probabilities are influenced by a number of factors, including site-specific characteristics, weather conditions and hour of day (JUNG et al., 2000). Nevertheless, long-time monitoring studies in species such as Ambystoma maculatum (BLACKWELl et al., 2004) and Ambystoma tigrinum (Whiteman \& WISSINGER, 2005) have revealed fluctuations in population size between years.

After comparing rainfall data and animal abundance, we detect an obvious relationship between population density and weather conditions. We obtained the greatest values for captures, population size and recruitment when rainfall levels were high. It has been generally accepted that moisture, as expressed in the amount and distribution of rainfall, exerts the greatest influence on the distribution of organisms in tropical environments (AUBERT DE LA RÜE et al., 1957; RichaRDS, 1957 in ViaL, 1968). Similar responses to annual distribution of rainfall have been reported for Bolitoglossa subpalmata (VIAL, 1968), Batrachoseps spp. (HENDRICKSON, 1954; ANDERSON, 1960) Aneides lugubris (Rosenthal, 1957) and Ensatina spp. (STEBBINS, 1954).

Available information on population densities of salamander comes from a limited number of studies that employ a variety of techniques (ViaL, 1968). Among neotropical salamanders, densities have been reported only for B. subpalmata, ranging from 0.0756 to 0.9097 individuals / $\mathrm{m}^{2}$ (VIAL, 1968), being the present study the second report so far. In general, there is a great variation in local population densities for plehodontids; TEST \& Bingham (1948) reported 0.0496 individuals $/ \mathrm{m}^{2}$ of Plethodon cinereus, and 
then BURTON \& LIKENS (1975) estimated for the same species densities ranging from 2.3670 to 2.5830 individuals $/ \mathrm{m}^{2}$. Estimated densities for other salamanders include 0.0070 individuals $/ \mathrm{m}^{2}$ in Plethodon yonablossee, 0.0220 individuals / $\mathrm{m}^{2}$ in Plethodon jordani (Gordon et al., 1962), 0.4180-0.8440 individuals / $\mathrm{m}^{2}$ in Plethodon glutinosus (SEMLITSCH, 1980), 0.4051-0.4989 individuals $/ \mathrm{m}^{2}$ in A. lugubris (ANDERSON, 1960), 0.10-0.25 individuals / $\mathrm{m}^{2}$ in Aneides aeneus (GORDON, 1952) and 0.1482-0.1729 individuals $/ \mathrm{m}^{2}$ in Ensatina eschscholtzii (STEBBINS, 1954). Unfortunately, most reports on population densities of plethodontids were calculated before herpetologists could deal with imperfect detection through more sophisticated approaches, which ultimately served to avoid repercussions of poor detection on the assessment of population size, population density and any other vital rate.

Survivorship is dependent upon finding an adequate refuge to obtain protection from predators and desiccation (SMYERS et al., 2002). Husting (1965) reported survival rates of 0.72 for males and 0.60 for females in a Michigan population of $A$. maculatum, and BLACKWELL et al. (2004) also reported high survival rates in a population of this species from Alabama, which led them to the conclusion that adult survival was the largest contributor to population growth in $A$. maculatum. In the most comprehensive study of survivorship of plethodontids, ORGAN (1961) calculated life tables for five species of Desmognathus and showed that there was a progressive increase in early survival rate from the most aquatic species, D. quadramaculatus, to the most terrestrial one, $D$. wrighti.

Survivorship estimates for $B$. altamazonica including all captured animals are quite high and did not vary too much. However, we must take into account that we calculated apparent survivorship and not real survival rates, because without conducting a more exhaustive study it was not possible to attribute losses in the population to deaths or emigration accurately. Generally, adult survival is likely to be more important than recruitment for population persistence, because it determines how long a population can persist without recruiting new individuals (SCHMIDT et al., 2005).

The sex ratios obtained during the present study showed a predominant proportion of females in the breeding population, which is in agreement with data reported for several species of plethodontid salamanders like Plethodon vehiculum, Plethodon dunni (Dumas, 1956), P. yonahlossee (Pope, 1950), D. quadramaculatus (ORGAN, 1961) and A. maculatum (BLACKWELl et al., 2004). This unbalanced sex ratio cannot be attributed to differential mortality, as we found homogeneity across sexes and ages in survival rates. A possible reason to explain our result would be that B. altamazonica males do not exhibit philopatry. On the contrary, other plethodontids such as $P$. cinereus (TEST \& Bingham, 1948), A. aeneus (Gordon, 1952), Desmognathus fuscus, Desmognathus carolinensis, D. wrighti (ORGAN, 1961) and Eurycea wilderae (BRUCE, 1988) show sex ratios unbalanced in favour of males. Finally, for B. subpalmata (VIAL, 1968) and Bolitoglossa nicefori (ORTEGA et al., 2009) there is no bias between sexes, even though they belong to the same genus as our study species. Differences in sex ratios for species belonging to the same genus have been also reported in Plethodon and Desmognathus. 
Although sex ratio varied slightly among months, there was on average three females per male. In some species of Desmognathus, variations in sex ratio over time are due to the fact that females move to the aquatic habitat during brooding. That is not the case for B. altamazonica, whose nesting microhabitats offer optimal conditions and are commonly used also by nonreproducing members of the population. Such a pattern of habitat use has been described also for B. subpalmata (VIAL, 1968).

Data reported here are a baseline essential for evaluating population changes over time, and for assessing relationships between salamander populations and environmental factors. The present study can be used as a starting point for comparison to other $B$. altamazonica populations along the wide range of distribution of the species; such comparisons will be useful when planning mitigation or restoration projects.

\section{Acknowledgement}

The environmental manager of Jardín Botánico de Villavicencio and E. Gomez provided access to the study place. R. MorenoArias and two anonymous reviewers provided helpful comments that greatly improved this manuscript. This project complies with all laws of Colombia and was conducted under CORMACARENA's scientific research permit (authorization No 000884), with funds provided by División de Investigaciones sede Bogotá - National University of Colombia (No 8003167) and equipments donated by IDEA WILD. This paper is from a portion of a M. Sc. Dissertation completed under the direction of J.D. Lynch and N. Ruiz-Rodgers at Universidad Nacional de Colombia.

\section{REFERENCES}

AMPHibiaWEB (2011). Information on Amphibian Biology and Conservation. University of California, Berkeley, California, USA. Available at http://amphibiaweb.org/. Retrieved on 09/09/2011.

Anderson, P.K. (1960). Ecology and evolution in island populations of salamanders in the San Francisco Bay region. Ecological Monographs 30: 359-386.

Angulo, A.; Rueda-Almonacid, J.V.; RodrígueZ-MaHECHA, J.V. \& LA MARCA, E. (2006). Técnicas de Inventario y Monitoreo para los Anfibios de la Región Tropical Andina. Series: Manuales de Campo, vol. 2 (J.V. RodríguezMahecha, J.V. Rueda-Almonacid \& A. González-Hernández, eds.). Conservación Internacional, Bogotá, Colombia.

AuberT DE LA RÜE, E. ; BOURLIÈRE, F. \& Harroy, J.-P. (1957). The Tropics. Knopf, New York.

Azevedo-Ramos, C.; Reichle, S.; AlmandÁriz, A \& Castro, F. (2009). Bolitoglossa altamazonica, In IUCN 2009. The IUCN Red List of Threatened Species. Version 2009.1. International Union for Nature Conservation and Natural Resources, Gland, Switzerland. Available at http:// www.iucnredlist.org. Retrieved on 08/04/2009.

Bayley, L.L.; Simons, T.R. \& Pollock, K.H. (2004). Estimating detection probability parameters for plethodontid salamanders using the robust capture-recapture design. Journal of Wildlife Management 68: 1-13.

Blackwell, E.A.; Cline, G.R. \& Marion, K.R. (2004). Annual variation in population estimators for a southern population of Ambystoma maculatum. Herpetologica 60: 304-311. 
BRUCE, R.C. (1988). An ecological life table for the salamander Eurycea wilderae. Copeia 1988: 15-26.

BurNhAM, K.P. \& ANDERSON, D.R. (2002). Model Selection and Multimodel inference: $A$ Practical Information-Theoretic Approach, 2nd ed. Springer, New York.

Burton, T.M. \& LiKENS, G.E. (1975). Salamander populations and biomass in the Hubbard Brook Experimental Forest, New Hampshire. Copeia 1975: 541-546. CRUMP, M.L. \& SCOTT, JR., N.J. (1994). Visual encounter survey, In W.R. Heyer, M.A. Donelly, R.W. McDiarmid, L.-A.C Hayek \& M.S. Foster (eds.) Measuring and Monitoring Biological Diversity. Standard Methods for Amphibians. Smithsonian Institution Press, Washington, D.C., USA, pp. 84-92.

DAugherTy, C.H. (1976). Freeze-branding as a technique for marking anurans. Copeia 1976: 836-838.

DONelly, M.A. \& GUYer, C (1994). Estimating population size: Mark-recapture, In W.R. Heyer, M.A. Donelly, R.W. McDiarmid, L.-A.C Hayek \& M.S. Foster (eds.) Measuring and Monitoring Biological Diversity. Standard Methods for Amphibians. Smithsonian Institution Press, Washington, D.C., USA, pp. 183-200.

Duellman, W.E. \& TRueb, L. (1994). Biology of Amphibians. The Johns Hopkins University Press, Baltimore, Maryland, USA. DumAS, P.C. (1956). The ecological relations of sympatry in Plethodon dunni and Plethodon vehiculum. Ecology 37: 484-495.

FEDER, M.E. (1982). Thermal ecology of neotropical lungless salamanders (Amphibia: Plethodontidae): environmental temperatures and behavioral responses. Ecology 63: 1665-1674.
Flatt, T.; Dummermuth, S. \& Anholt, B.R. (1997). Mark-recapture estimates of survival in populations on the asp viper, Vipera aspis aspis. Journal of Herpetology 31: 558-564.

GORDON, R.E. (1952). A contribution to the life history and ecology of the plethodontid salamander Aneides aeneus (Cope and Packard). American Midland Naturalist 47: 666-701.

Gordon, R.E.; MacMahon, J.A. \& WAKE, D.B. (1962). Relative abundance, microhabitat, and behavior of some southern Appalachian salamanders. Zoologica 47: 9-14. Gutiérrez-Lamus, D.L. (2009). Tamaño Poblacional, Reclutamiento, Microhábitat y Uso del Espacio en una Población de Bolitoglossa altamazonica (Caudata: Plethodontidae) Presente en el Jardín Botánico de Villavicencio. M.Sc. Dissertation. Universidad Nacional de Colombia, Bogotá, Colombia.

Hecnar, S.J. \& M'Closkey, R.T. (1996). Regional dynamics and the status of amphibians. Ecology 77: 2091-2097.

Hendrickson, J.R. (1954). Ecology and systematics of salamanders of the genus Batrachoseps. University of California Publications in Zoology 54: 1-46.

Holdridge, L.R.; GRENKE, W.C.; HathewaY, W.H.; LIANG, T \& TOSI, JR., J.A. (1971). Forest Environments in Tropical Life Zones: A Pilot Study. Pergamon Press, Oxford, UK.

Husting, E.L. (1965). Survival and breeding structure in a population of Ambystoma maculatum. Copeia 1965: 352-362.

Jolly, G.M. (1965). Explicit estimates from capture-recapture data with both death and immigration-stochastic model. Biometrika 52: 225-247.

Jung, R.E.; Droege, S.; Sauer, J.R. \& Landy, R.B. (2000). Evaluation of terrestrial and streamside salamander monitoring techniques at 
Shenandoah National Park. Environmental Monitoring and Assessment 63: 65-79.

Krebs, C.J. (1999). Ecological Methodology, $2^{\text {nd }} e d$. Addison Wesley Longman, Menlo Park, California, USA.

Kvarnemo, C. \& Ahnesjö, I. (2002). Operational sex ratios and mating competition, In I.C.W. Hardy (ed.) Sex Ratios. Concepts and Research Methods. Cambridge University Press, Cambridge, UK, pp. 366-382.

LEBRETON, J.-D.; BURNhAM, K.P.; ClOBERT, J. \& ANDERSON, D.R. (1992). Modeling survival and testing biological hypotheses using marked animals: a unified approach with case studies. Ecological Monographs 62: 67-118.

LIPS, K.R. (1998). Decline of a tropical montane amphibian fauna. Conservation Biology 12: 106-117.

Mazerolle, M.J.; Bailey, L.L.; Kendall, W.L.; Royle, J.A.; CONVERSE, S.J. \& NiCHOLS, J.D. (2007). Making great leaps forward: accounting for detectability in herpetological field studies. Journal of Herpetology 41: 672-689.

NishikaWA, K.C \& Service, P.M. (1988). A fluorescent marking technique for individual recognition of terrestrial salamanders. Journal of Herpetology 22: 351-353.

Olgun, K.; Miaud, C \& Gautier, P. (2001). Age, growth, and survivorship in the viviparous salamander Mertensiella luschani from southwestern Turkey. Canadian Journal of Zoology 79: 1559-1567.

Organ, J.A. (1961). Studies of the local distribution, life history, and population dynamics of the salamander genus Desmognathus in Virginia. Ecological Monographs 31: 189-220.

Ortega, J.E.; Monares-Riaño, J.M \& RAMíREZ-PINILLA, M.P. (2009). Reproductive activity, diet, and microhabitat use in
Bolitoglossa nicefori (Caudata: Plethodontidae). Journal of Herpetology 43: 1-10.

Parra-Olea, G.; García-París, M. \& WAKE, D.B. (1999). Status of some populations of Mexican salamanders (Amphibia: Plethodontidae). Revista de Biología Tropical 47: 217-223.

PechmanN, J.H.K. \&Wilbur, H.M. (1994). Putting declining amphibian populations in perspective: natural fluctuations and human impacts. Herpetologica 50: 65-84.

PechmanN, J.H.K.; SCOTT, D.E.; Semlitsch, R.D.; Caldwell, J.P.; VitT, L.J. \& GibBons, J.W. (1991). Declining amphibian populations: the problem of separating human impacts from natural fluctuations. Science 253: 892-895.

Pledger, S.; Pollock, K.H. \& Norris, J.L. (2003). Open capture-recapture models with heterogeneity: I. Cormack-JollySeber model. Biometrics 59: 786-794.

Pollock, K.H; Nichols, J.D.; BROwnIE, C. \& Hines, J.E. (1990). Statistical inference for capture-recapture experiments. Wildlife Monographs 107: 1-97.

Pope, C.H. (1950). A statistical and ecological study of the salamander, Plethodon yonahlossee. Bulletin of the Chicago Academy of Sciences 9: 79-106.

Pounds, J.A.; Fogden, M.P.L.; SAVAGE, J.M. \& Gorman, G.C. (1997). Test of null models for amphibian declines on a tropical mountain. Conservation Biology 11: 1307-1322.

PRADEL, R. (1996). Utilization of capturemark-recapture for the study of recruitment and population growth rate. Biometrics 52: 703-709.

Ranta, E.; Lummaa, V.; Kaitala, V. \& MERILÄ, J. (2000). Spatial dynamics of adaptive sex ratios. Ecology Letters 3: 30-34. 
RichaRdS, P.W. (1957). The Tropical Rain Forest: An Ecological Study. Cambridge University Press, Cambridge, UK.

ROSENTHAL, G.M. (1957). The role of moisture and temperature in the local distribution of the plethodontid salamander Aneides lugubris. University of California Publications in Zoology 54: 371-420.

Rovito, S.M.; Parra-Olea, G.; VásqueZAlmazán, C.R.; Papenfuss, T.J. \& WAKE, D.B. (2009). Dramatic declines in neotropical salamander populations are an important part of the global amphibian crisis. Proceedings of the National Academy of Sciences USA 106: 3231-3236. SCHMidT, B.R.; FELdmanN, R. \& SCHAUb, M. (2005). Demographic processes underlying population growth and decline in Salamandra salamandra. Conservation Biology 19: 1149-1156.

SEBER, G.A.F. (1965). A note on the multiplerecapture census. Biometrika 52: 249-259.

Semlitsch, R.D. (1980). Geographic and local variation in population parameters of the slimy salamander Plethodon glutinosus. Herpetologica 36: 6-16.

SMYers, S.D.; RUbBo,M.J.; TownSEND, JR., W.R. \& SWART, C.C. (2002). Intra- and interspecific characterizations of burrow use and defense by juvenile ambystomatid salamanders. Herpetologica 58: 422-429.

SpOTILA, J.R. (1972). Role of temperature and water in the ecology of lungless salamanders. Ecological Monographs 42: 95-125.

STEBBINS, R.C. (1954). Natural history of the salamanders of the plethodontid genus Ensatina. University of California Publications in Zoology 54: 47-123.

STUART, S.N.; CHANSON, J.S.; COX, N.A.; Young, B.E.; RODRIGUES, A.S.L.; FISCHMAN,
D.L. \& WalleR, R.W. (2004). Status and trends of amphibian declines and extinctions worldwide. Science 306: 1783-1786.

Test, F.H. \& Bingham, B.A. (1948). Census of a population of the red-backed salamander (Plethodon cinereus). American Midland Naturalist 39: 362-372.

VIAL, J.L. (1968). The ecolology of the tropical salamander, Bolitoglossa subpalmata, in Costa Rica. Revista de Biología Tropical 15: 13-115.

WAKE, D.B. (1966). Comparative osteology and evolution of the lungless salamanders, family Plethodontidae. Memoirs of the Southern California Academy of Sciences 4: 1-111.

White, G.C. \& Burnham, K.P. (1999). Program MARK: survival estimation from populations of marked animals. Bird Study 46: S120-S139.

Whiteman, H.H. \& Wissinger, S.A. (2005). Amphibian population cycles and long-term data sets, In M. Lannoo (ed.) Amphibian Declines. The Conservation Status of United States Species. University of California Press, Berkeley, California, USA, pp. 177-184.

Whitfield, S.M.; Bell, K.E.; PHILIPPI, T.; SASA, M.; Bolaños, F.; Chaves, G.; SAVAGe, J.M. \& Donnelly, M.A. (2007). Amphibian and reptile declines over 35 years at La Selva, Costa Rica. Proceedings of the National Academy of Sciences USA 104: 8352-8356.

Willson, J.D.; Winne, C.T. \& TodD, B.D. (2011). Ecological and methodological factors affecting detectability and population estimation in elusive species. Journal of Wildlife Management 75: 36-45.

Zug, G.R.; VitT, L.J. \& Caldwell, J.P. (2001). Herpetology. An Introductory Biology of Amphibians and Reptiles, $2^{\text {nd }}$ ed. Academic Press, San Diego, California, USA. 